\title{
Investigating Determinants of Behavioural Intention to Accept Technology of Zimbabwean Teacher Education Colleges Lecturers
}

\author{
Havatidi Madzamba*, Desmond Wesley Govender \\ Computer Science Education Department, University of KwaZulu-Natal, Durban, South Africa
}

Received April 5, 2021; Revised May 18, 2021; Accepted June 15, 2021

\section{Cite This Paper in the following Citation Styles}

(a): [1] Havatidi Madzamba, Desmond Govender , "Investigating Determinants of Behavioural Intention to Accept Technology of Zimbabwean Teacher Education Colleges Lecturers," Universal Journal of Educational Research, Vol. 9, No. 7, pp. 1369 - 1374, 2021. DOI: 10.13189/ujer.2021.090703.

(b): Havatidi Madzamba, Desmond Govender (2021). Investigating Determinants of Behavioural Intention to Accept Technology of Zimbabwean Teacher Education Colleges Lecturers. Universal Journal of Educational Research, 9(7), 1369 - 1374. DOI: 10.13189/ujer.2021.090703.

Copyright $@ 2021$ by authors, all rights reserved. Authors agree that this article remains permanently open access under the terms of the Creative Commons Attribution License 4.0 International License

\begin{abstract}
The use of technology has necessarily invaded all aspects of our lives. One such area is education, especially that of lecturers at teacher training colleges. However, availability of technology in the education system does not necessarily mean the use of technology. Acceptance of technology use by individuals is critical to the successful implementation of technology in teacher training. Therefore, there is a need to research factors that determine the intention to use technology. Researchers have listed numerous variables that influence the intention to use the technology in various aspects of education. This article aimed to determine whether age, gender and academic qualification influence lecturers' behavioural intention to accept and use technology. Data were collected from lecturers in 10 teacher-training colleges using a unified theory of acceptance and use of technology (UTAUT)-based questionnaire. SPSS (v. 20) descriptive statistics were used in data analysis. The results indicated that gender, age and level of education have no influence on the behavioural intention to accept and use technology. These findings provide important practical implications, which must be considered in technology training of teacher training college lecturers.
\end{abstract}

Keywords Technology in Teacher Education, Technology Acceptance, Unified Theory of Acceptance and Use of Technology (UTAUT)

\section{Introduction}

The use of technology has expanded in all educational environments, including teacher-training colleges. Technology has become an almost inevitable tool for education. The use of it has made other avenues more effective in teaching and learning than the traditional methodologies. It has the potential to transform education from teacher-centred to student-centred [1]. Governments worldwide have recognised the significance of the role of technology in education and it has resulted in substantial capital inflows into the area [2]-[4]. As a result, there is need for frontline personnel to have skills and knowledge to manipulate these technologies in education. However, availability of a technology in teachers' training colleges does not necessary result in acceptance and use. In these institutions, lecturers play a crucial role in the modelling of technology use to the pre-service teachers. Policymakers in Higher and Tertiary Education of Zimbabwe have required that newly qualified teachers exiting pre-service training should be proficient in pedagogical technology. The challenge is how colleges and other tertiary institutions develop future teachers who are able to use modern technologies to improve students' learning. The success of the introduction and use of technology hinges on the technology acceptance by the lecturers. It is crucial therefore, to understand some factors that influence lecturers' acceptance of technology. 
Research has shown that numerous demographic factors play a role in the decision to accept or not to accept technology [5]-[7]. Such demographics include, among others, gender, age, level of education, working experience and self-efficacy [8], [9]. The focus of this paper is to explore teacher training college lecturers' behavioural intention to accept technology from a gender, age and academic qualification perspective. Many proposed models explain variables that influence a person's decision to accept and use a particular technology.

The Unified Theory of Acceptance and Use of Technology (UTAUT) [10], is a parsimonious model used to explain individual and organisational acceptance of technology. The theory embodies constructs from eight different models and theories, which predict usage behaviour intention. These are Theory of Reasoned Action (TRA) [11], the Motivational Model (MM) [12], the Model of Personal Computer Utilisation (MPCU) [13], the Technology Acceptance Model (TAM) [11], the Theory of Planned Behaviour (TPB) [14], Innovation Diffusion Theory (IDT) [15], the Social Cognitive Theory (SCT) [16]. The integration reduced 32 constructs to four variables: performance expectance, effort expectance, social influence and facilitating conditions. These four variables are considered as determinants of behaviour intention of an individual faced with a technological innovation. This paper is intended to discuss how the variables age, gender and level of education may influence, if any, these four UTAUT constructs in their determination of behavioural intention to use technology.

Technology cannot contribute unless it is used, but people sometimes do not use systems or innovations that could potentially increase their performance [17]. For lecturers in teacher training colleges to start using technology there is need for them to appreciate its usefulness in their research and teaching, and in the learning of students. This appreciation can then lead to the desire to use or adopt the technology. However, this requires some level of change in the views, perceptions and attitudes towards the technology, which leads to a positive behavioural intention to acceptance and use of technology. Do age, gender and academic qualification have any role in the acceptance and use of technology?

From a gender perspective, there seems to be a general societal thinking that technological skills are not equally distributed in the current environment [6]. There is a perception that women are timid when it comes to issues like using technology. Men are believed to be more confident when interacting with technology. A comparison done between British and Chinese respondents showed that men were more confident of their computer skills than women [18]. On acceptance of technical skills, literature also shows that women have less confidence, compared to men [19]. Using the UTAUT framework, we can check how the gender, age and academic qualification variables influence the four constructs, which are determinants of behavioural intention to accept and use technology. Some studies declare contrasting findings on the role of gender on behavioral intention.

Literature has contrasting views on role of age on behavioural intention. On one hand, some argue that the age variable has a significant impact on behavioural intention to adopt an innovation [20]; [21]. Different ages are exposed to different levels or depths of ICT innovations and usage. This results in the different attitudes, intentions and skills level. Older workers have less enthusiasm towards the adoption of innovative technologies [10]. It might appear that lecturers exposed to technology during their training are bound to have contrasting attitudes and skills from those who have had no exposure. On the other hand, others suggest that age is not a significant factor [22]. Individuals adopt technologies regardless of their age. [23].

Among the many determinants, level of education is one of the most reliable factors used to predict intention to use technology [24]. There are several reasons why education has such an influence. People with higher educational level have more cognitive resources [25], which enable them to venture, learn and assimilate new materials. These cognitive skills affect different educational groups differently. These resources have a major influence on the differences in internet use and digital skills of different educational groups. Research has also shown that those with higher education are likely to possess a computer and access the internet [26] giving them the opportunity to explore privately and at their own pace. A personal computer gives more time to practise what might have been learnt in group workshops. Access to the internet gives such people a head start on those who do not have it. People with lower qualifications have lower internet manipulation skills [6], [27]. The latter might use internet only for social pleasure; hence, they lag behind in the use of technology in educational environments.

Do these three variables have any influence on the lecturer's behavioural intention to accept and use technology in their day-to-day teaching, research and administration? We therefore formulated the following research question:

Do the lecturers' age, gender and level of qualification have any influence on behavioural intention to accept and use technology?

\section{Materials and Methods}

This study was a descriptive survey. Quantitative methods which were pre-determined, using instrument-based technique, statistical data analysis and interpretation packages. In other words, the procedures for data collection, analysis and interpretation are set before 
data collection and they do not emerge as research progresses.

\subsection{Research Participants}

The population was lecturers from Zimbabwean teacher training colleges. Such colleges can be training primary or secondary pre-service teachers. In the study, there were fourteen teachers' colleges (three secondary and eleven primary) distributed among the ten administrative provinces. A sample of 225 lecturers was drawn, through simple random sampling, from 10 teacher-training colleges (three secondary and seven primary). Participants belonged to different college academic departments. Details of the demographic aspects are presented in Table 1.

Table 1. Demographic Details of Participants

\begin{tabular}{|c|c|c|c|}
\hline $\begin{array}{c}\text { Demographic } \\
\text { feature }\end{array}$ & Category & Frequency & Percentage \\
\hline \multirow{3}{*}{$\begin{array}{c}\text { Gender of } \\
\text { respondents }\end{array}$} & Female & 108 & 48.0 \\
\hline & Male & 117 & 52.0 \\
\hline & 20 to 30 & 6 & 2.7 \\
\hline \multirow{5}{*}{$\begin{array}{c}\text { Age of } \\
\text { respondents }\end{array}$} & 31 to 40 & 18 & 8.0 \\
\hline & 41 to 50 & 116 & 51.6 \\
\hline & 51 to 60 & 80 & 35.6 \\
\hline & $60+$ & 5 & 2.2 \\
\hline & Diploma & 2 & .9 \\
\hline \multirow{4}{*}{$\begin{array}{c}\text { Educational } \\
\text { qualifications }\end{array}$} & $\begin{array}{l}\text { Bachelor's } \\
\text { degree }\end{array}$ & 46 & 20.4 \\
\hline & Honours & 23 & 10.2 \\
\hline & Master’s & 141 & 62.7 \\
\hline & Doctorate & 12 & 5.3 \\
\hline \multirow[t]{7}{*}{ Teaching area } & $\begin{array}{l}\text { Professional } \\
\text { development }\end{array}$ & 65 & 28.9 \\
\hline & Languages & 21 & 9.3 \\
\hline & $\begin{array}{l}\text { Practical } \\
\text { subjects }\end{array}$ & 42 & 18.7 \\
\hline & Sciences & 44 & 19.6 \\
\hline & ICT & 11 & 4.9 \\
\hline & Other & 42 & 18.7 \\
\hline & Total & 225 & 100 \\
\hline
\end{tabular}

\subsection{Research Methods and Data Collection}

A self-reporting, five-point Likert scale-type questionnaire consisting of 51 items adapted from the publications of Schmidt et.al. [28] was used. The Likert scale ranged from one (strongly disagree) to five (strongly agree) with three as a neutral point. The questionnaire was administered after receiving consent from the college administration and participants of each selected college. This study extracted items from the four UTAUT constructs only for analysis. The data was capture onto SPSS data sheet and analysed using SPSS (v. 20) descriptive statistics, which included frequencies, percentages, mean scores and standard deviation. Since the research focused on comparing the mean scores of more than two academic groups, we used analysis of variance (ANOVA). In this paper, we focused on qualification as the independent variable (factor) with five different qualification levels, as shown in Table 1.

In the discussion of mean scores we have categorised acceptance into three levels: Low $(1.00 \leq \overline{\mathbf{x}} \leq 2.50)$; Moderate $\quad(2.50 \leq \overline{\mathbf{x}} \leq 3.50) ; \quad$ High $\quad(3.50 \leq \overline{\mathbf{x}} \leq 5.00) \quad$ as suggested by [29].

\section{Results}

\subsection{Demographics}

Table 1 above details respondents' demographic profiles. Out of 225 respondents, males were in the slight majority (52\%). A greater number of respondents indicated their age as between 41 and 50 years $(n=118$, $40.8 \%$ ), while the minority were 60 or above ( $\mathrm{n}=5$, $2.2 \%)$. Regarding the highest academic qualification, the majority of the respondents $(n=141,62.7 \%)$ had Master's degrees. Generally, at least a first degree is required for one to qualify to be a teachers' college lecturer. Ph.D. holders are usually expected to be in universities but there is a new trend of such holders being in teachers' colleges. Almost all colleges sampled had at least one lecturer who was Ph.D. Of late, there is a constricted uptake of such people into universities.

\subsection{Age and Behavioural Intention to Accept and Use Technology}

A one-way between-groups ANOVA was conducted to explore the impact of age on levels of behavioural intention to use technology. Subjects were divided into five groups according to their age. The mean scores for all age groups were high $(\overline{\mathrm{x}} \geq 3.50)$. In the comparison the 31-to-40-year group had the highest mean score $(\mathrm{n}=18, \overline{\mathrm{x}}$ $=4.15$ ). There was no statistically significant difference at the $\mathrm{p}<.05$ level in UTAUT scores for the five age groups (F 1.59; $\mathrm{p}=.176$ ).

Table 2. One-way ANOVA on Age Groups

\begin{tabular}{cccccc}
\hline & $\begin{array}{c}\text { Sum of } \\
\text { Squares }\end{array}$ & df & $\begin{array}{c}\text { Mean } \\
\text { Square }\end{array}$ & F & Sig \\
\hline $\begin{array}{c}\text { Between } \\
\text { Groups }\end{array}$ & 1.348 & 4 & .337 & 1.598 & .176 \\
$\begin{array}{c}\text { Within } \\
\text { Groups }\end{array}$ & 46.373 & 220 & .211 & & \\
Total & 47.721 & 224 & & & \\
\hline
\end{tabular}

(Age groups: group 1: 20 to 30; group 2: 31 to 40 ; group 3: 41 to 50; group 5:51 to 60 ; group 5: $60+$ )

\subsection{Gender and Behavioural Intention to Accept and Use Technology}

An independent-samples t-test compared the 
behavioural intention mean scores for females and males. There was no significant difference in behavioural mean scores for males ( $\overline{\mathbf{x}}=3.84$ ) and females ( $\overline{\mathbf{x}}=3.74), \mathrm{p}=.21$ ).

Table 3. T-test Gender and Behavioural Intention

\begin{tabular}{ccc}
\hline \multicolumn{3}{c}{ t-Test: Two-Sample Assuming Unequal Variances } \\
\hline Mean & Female & Male \\
Variance & 3.737037 & 3.844274 \\
Observations & 0.4385 & 0.402344 \\
Hypothesised Mean & 108 & 117 \\
Difference & 0 & \\
df & 220 & \\
t Stat & -1.23834 & \\
$\mathbf{P}(\mathbf{T}<=$ t) one-tail & 0.108455 & \\
$\mathbf{t}$ Critical one-tail & 1.651809 & \\
$\mathbf{P}(\mathbf{T}<=\mathbf{t})$ two-tail & 0.216909 \\
$\mathbf{t}$ Critical two-tail & 1.970806 \\
\hline
\end{tabular}

\subsection{Qualification and Behavioural Intention to Accept and Use Technology}

Table 4 below presents the computed mean scores and standard deviation for each qualification group.

Table 4. Level of Qualification and Behavioural Intention to Accept and Use Technology

\begin{tabular}{cccc}
\hline Qualification & $\mathbf{N}$ & $\overline{\mathbf{x}}$ & Std. Deviation \\
\hline Diploma & 2 & 4.20 & .679 \\
Bachelor's degree & 46 & 3.79 & .460 \\
Honours degree & 23 & 3.88 & .501 \\
Master's degree & 141 & 3.87 & .438 \\
Doctorate degree & 12 & 3.69 & .613 \\
Overall UTAUT & & 3.85 & .460 \\
mean & & & \\
\hline
\end{tabular}

Note: Low (1.00 $\leq \overline{\mathrm{x}} \leq 2.50)$; Moderate $(2.50 \leq \overline{\mathbf{x}} \leq 3.50)$; High (3.50 $\leq$ $\overline{\mathrm{x}} \leq 5.00)$

Mean scores for all the groups are in the high category $(3.50 \leq \overline{\mathbf{x}} \leq 5.00)$ according to the suggested scale. This suggests that lecturers sampled had a high $(\overline{\mathbf{x}}=3.85)$ technology acceptance level. The diploma holders seemed to have higher acceptance level $(\overline{\mathbf{x}}=4.20, \mathrm{SD}=.67)$, but this may be unrepresentative because there were only two such respondents. The Ph.D. holders have the lowest mean score. Although the scores seem different, it was important to establish if the differences had any statistical significance across the groups. A one-way between-groups analysis of variance (ANOVA) was conducted to explore the impact of qualification on acceptance level. Participants were divided into five groups according to their highest level of qualification (Group 1: Diploma; Group 2: Bachelor's; Group 3: Honours; Group 4: Master's; Group 5: Doctorate).
Table 5. One-Way ANOVA Qualification and Behavioural Intention

\begin{tabular}{cccccc}
\hline \multicolumn{7}{c}{$\begin{array}{c}\text { Behavioural intention } \\
\text { Sum of } \\
\text { Squares }\end{array}$} & df & $\begin{array}{c}\text { Mean } \\
\text { Square }\end{array}$ & F & Sig. \\
\hline $\begin{array}{c}\text { Between } \\
\text { Groups }\end{array}$ & .991 & 4 & .248 & .892 & .469 \\
$\begin{array}{c}\text { Within } \\
\text { Groups } \\
\text { Total }\end{array}$ & 60.783 & 219 & .278 & & \\
\hline
\end{tabular}

Table 5 shows that there was no statistically significant difference at the $\mathrm{p}<0.05$ level in the behaviour intention mean scores $[\mathrm{F}(4,219)=.892 ; \mathrm{p}<.469]$ of different qualifications. Therefore, a lecturer's educational level has no impact on the behavioural intention to accept and use technology.

The findings have important implications for the lecturer technology training programs in teacher education.

\section{Discussion}

Acceptance of technology is critical because it is the starting point for technology use. In other words, one cannot use an innovation before accepting it. If there is acceptance by the intended user developmental programs can then be designed to empower the user. The basic framework of this study is the UTAUT model of [10]. This model addresses the intention to use a technology as a measure of acceptance of technology. Based on this study results, we came to the following conclusions.

The sampled lecturers' age, gender and academic qualifications did not have significant influence on the lecturers' behavioural intention to accept and use technology in their day-to-day academic chores. The results of this study are discussed on the basis of the results variables analysed.

\subsection{Age}

Our finding reflected that age has no effect on the behaviour intention determinants. This in contradiction to some existing research [9], [30], [31]. The existing literature states that younger people have a stronger propensity to accept and use technology. One possible reason for our finding is that lecturers have been exposed to computers, laptops or smart phones at home and at work. The ubiquity of technology, which has been with us now for more than a decade, has led lecturers to acknowledge the importance of accepting technology as a critical component of life. Another contributing factor is that our participating lecturers' level of education has exposed them to technology, which out-balanced the variables considered. The older people probably got their higher qualifications later in their professional life, which coincided with the technology innovation wave, so they 
were compelled by circumstances to readjust their technological perceptions. The threat of being replaced by technology or younger technology-savvy lecturers might also have pressed the older participants to pressure themselves as far technology acceptance and use were concerned.

\subsection{Gender}

Different studies conducted by [19], [32] and [33] have concluded that gender has a moderating effect on technology acceptance. Our study found otherwise that lecturers of both genders show no difference in their level of technology acceptance. Maybe in future we would have analysed the relationship between gender and the individual UTAUT constructs (performance expectancy (PE), effort expectancy (EE), social influence (SI) and facilitating conditions (FC) different results will have been found.

\subsection{Qualifications}

References [24], [34]-[36], among others, concluded that the level of qualification greatly predicts the behavioural intention to use technology. Our contrasting finding might have been caused by the fact that this study comes almost five years after the Ministry of Higher and Tertiary Education had declared that teachers' colleges must produce technology-compliant pre-service teachers. This time lapse has probably given lecturers of all academic levels time to adjust their position on technology as a tool in education. Probably the difference will show when it comes to the actual use of technology, considering that the higher the education level the higher the exposure to technology. Another possible reason is that lecturers have been learning the use of technology by themselves not through formal settings, since there is no formal training in technology integration.

\section{Conclusion}

The finding is valuable in that there is no need to focus on any of these demographic variables when considering the designing and mounting of technology-training programmes by those responsible. This has advantages in that there will be less expenditure because there will be no grouping that will be targeted for training. If not, it would have meant that different age, gender or qualification groups would be trained separately. In this case the focus is on lecturer professional development.

For the future, one might want to consider using the "actual use of technology" as the dependent variable instead of "behavioural intention" to use. Behavioural intention captures the extent to which people are willing to try to perform a behaviour, [14], but it might simply remain as an intention. An intention might fail to translate to actual behaviour, which in this case is actual technology use in teaching and learning.

The findings of this study may not be generalised to all teachers' college lecturers in Zimbabwe. The participants were selected from a population accessed based on the proximity of the colleges to the researcher due to limited financial resources. Such studies rely on the honesty of the participants. Whereas we consider lecturers as professional, some might have perceived it too sensitive to reveal their actual standing on their technology competence. In this age, one might want to sound more technology shrewd than what one really is. Possibly a wider and more inclusive sample will produce generalisable findings.

\section{REFERENCES}

[1] Noh N., M., Hamzah M., Abdullah N., "The influence of demographic factor on personal innovativeness towards technology acceptance," Malaysian Online Journal of Educational Technology, 4(1), 68-75, 2016.

[2] Adam L., "Information and communication technologies in higher education in africa: initiatives and challenges," Jhea/Resa, 1(1), 195-221, 2003.

[3] Jung I., "ICT-pedagogy integration in teacher training: Application cases worldwide," Educational Technology and Society, 8(2), 94-101, 2005.

[4] Teeroovengadum V., Heeraman N., Jugurnath B., "Examining the antecedents of ICT adoption in education using an extended technology acceptance Model (TAM)," International Journal of Education and Development Using Information and Communication Technology (IJEDICT), 13(3), 4-23, 2017.

[5] Joo YJ., Park S., Lim E., "Factors influencing preservice teachers' intention to use technology: TPACK, Teacher Self-efficacy, and Technology Acceptance Model,” Educational Technology \& Society, 21(3), 48-59, 2018.

[6] Van Deursen AJ., van Dijk JA., Peters O., "Rethinking Internet skills: The contribution of gender, age, education, internet experience, and hours online to medium- and content-related Internet skills,” Poetics, 39(2), 125-144, 2011. doi: 10.1016/j.poetic.2011.02.001.

[7] Jamieson-Proctor RM., Burnett PC., Watson G., Finger G., "ICT integration and teachers' confidence in using ICT for teaching and learning in Queensland state schools," Australasian Journal of Educational Technology, 22(4), 511-530, 2006.

[8] Buabeng-Andoh C. 'Factors influencing teachers' adoption and integration of information and communication technology into teaching: A review of the literature Charles Buabeng-Andoh," International Journal of Education and Development Using Information and Communication Technology, 8(1), 136-155, 2012.

[9] Afshari M., Bakar K. A., Luan W. S., Samah B. A., Fooi F. S. "Factors affecting teachers' use of information," 
International Journal of Instruction, 2(1), 2009. Retrieved from

https://www.researchgate.net/publication/26571454_Factors _affecting_teachers'_use_of_information_and_communicati on_technology

[10] Venkatesh V., Morris, MG., Daxis GB., Davis FD., “User acceptance of information technology: Toward a unified view,”. MIS Quarterly, 27(3), 425-478, 2003.

[11] Davis FD., Bagozzi RP., Warshaw PR. "User acceptance of computer technology: A comparison of two theoretical models,” JSTOR, 35(8), 982-1003, 1989.

[12] Wu YT., "Research trends in technological pedagogical content knowledge (TPACK) research: A review of empirical studies published in selected journals from 2002 to 2011,”. British Journal of Educational Technology, 44(3), 2013. doi: 10.1111/j.1467-8535.2012.01349.x.

[13] Thompson RL, Higgins CA, Howell JM. "Personal computing: Toward a conceptual model of utilization," MIS Q Manag Inf Syst.15(1):125-142, 1991doi:10.2307/249443

[14] Ajzen I. "The theory of planned behaviour : Reactions and reflections,” Journal of Psychology \& Health, 26(9). 2011. doi:10.1080/08870446.2011.613995.

[15] Rogers EM., “Diffusion of Innovations Theory,” New York: Free Press, 5th ed. 2003. doi:10.1111/j.1467-9523.1970.tb0 0071.x.

[16] Bandura A., McClelland D. "Social Foundations of Thought and Action: A social cognitive theory," Soc Learn Theory. 1977;(October):12-29.

[17] Mathieson K., "Predicting user intentions : Comparing the technology acceptance model with the theory of planned behavior," Information Systems Research 2(3):173-191, 2016.

[18] Li N., Kirkup G., "Gender and cultural differences in Internet use: a study of China and the UK," Comput Educ. 2007;48(2):301-317. doi:10.1016/j.compedu.2005.01.007

[19] Volman M., Van Eck E., Heemskerk I., Kuiper E., "New technologies, new differences. Gender and ethnic differences in pupils' use of ICT in primary and secondary education," Comput Educ. 45(1):35-55, 2005. doi:10.1016/j.compedu.20 04.03 .001

[20] Morris M., Venkatesh V., "Age differences in technology adoption decisions: Implications for a changing work force," Personnel Psychology. 53. 375-403, 2000. doi: 10.1111/j.1744-6570.2000.tb00206.x.

[21] Johar MG., Awalluddin JA. "The Role of Technology Acceptance Model in Explaining Effect on E-Commerce Application System," Int J Manag Inf Technol. 2011;3(3):1-14. doi:10.5121/ijmit.2011.3301

[22] Albirini A. Teachers' attitudes toward information and communication technologies: the case of Syrian EFL teachers. Comput Educ. 2006; 47(4):373-398. doi:10.1016/j.compedu.2004.10.013

[23] Kurkinen E., "The effect of age on technology acceptance among field police officers," ISCRAM 2013 Conf Proc - 10th Int Conf Inf Syst Cris Response Manag. Published online 2013:468-477.

[24] Wittendorp R., (2017). "Modeling the use of e-government services : The role of internet skills, support sources, gender, age, education, internet experience, employment rate and income," (Doctoral dissertation, University of Twente). Retrieved from https://essay.utwente.nl/73684/1/R .H.J.\%20Wittendorp_MA_BMS\%20\%282017\%29\%20Mod eling\%20the\%20use\%20of\%20e-government\%20services\% 20The\%20role\%20of\%20internet\%20skills\%2C\%20support \%20sources\%2C\%20gender\%2C\%20age\%2C\%20educatio n\%2C\%20internet\%20experience\%2C\%20employment\%20 rate\%20and\%20income.pdf

[25] De Haan J., IT and social inequality in the Netherlands. IT Soc. 2003;1(4):27-45.

[26] Buente W., Robbin A., "Trends in internet information behavior, 2000-2004," $J$ Am Soc Inf Sci Technol.;59(11):1743-1760. 2008. doi:10.1002/asi.20883.

[27] Hargittai E., Second-level digital divide: Differences in people's online skills. First Monday. 2002;7(4). doi:10.5210/fm.v7i4.942

[28] Schmidt DA., Baran E., Thompson AD., Mishra P., Koehle, MJ., Shin TS., "Technological pedagogical content knowledge (TPACK)," Journal of Research on Technology in Education, 42(2), 123-149, 2009. doi:10.1080/15391523. 2009.10782544.

[29] Kumar N., Rose R.C., D’Silva JL., “Teachers' readiness to use technology in the classroom: An empirical study," European Journal of Scientific Research, 21(4), 603-616, 2008. doi: 10.1504/IJMIE.2008.016228.

[30] Wang YS., Wu MC., Wang HY., "Investigating the determinants and age and gender differences in the acceptance of mobile learning. British Journal of Educational Technology, 40(1), 92-118, 2009. doi: 10.1111/j.1467-8535.2007.00809.x.

[31] Goswami A, Dutta S. Gender Differences in Technology Usage - A Literature Review. 2016;(January):51-59.

[32] Joy J., “Factors persuading school teachers' acceptance of information and communication technology (ICT) in pedagogy," International Journal for Research in Engineering Application \& Management (IJREAM), 4(09), 2018.

[33] Basargekar P., Singhavi C. "Factors affecting teachers' perceived proficiency in using ict in the classroom," IAFOR Journal of Education 5(2), 67-84, 2017.

[34] Teo T., "Factors influencing teachers' intention to use technology: Model development and test," Computers \& Education, 57(4), 2432-2440, (2011). doi: /10.1016/j.compedu.2011.06.008. 